$\$=$

\title{
Hematological and immunological effects of gallium, indium, and arsenic in light emitting diodes manufacturing workers
}

\author{
Yeh-Hsiung Liao \\ Department of Health Sciences, School of Public Health, Kaohsiung Medical University, Taiwan \\ E-mail: bany0309@yahoo.com.tw
}

\begin{abstract}
Purpose: To determine whether hematological and immunological changes occur in manufacturing workers in association with gallium, indium, and arsenic biomarkers in light-emitting diodes.

Methods: 91exposed light-emitting diodes, workers and 24 referents were monitored for whole blood and urine levels of gallium, indium, and arsenic. Venous blood was also collected for routine and immunological analyses.

Results: The mean levels of blood in, urine Ga, urine as, and mean corpuscular hemoglobin concentration (MCHC) in the exposed workers were significantly than in referents. The values of mean corpuscular volume (MCV), white blood cell counts (WBCs), neutrophils, lymphocytes, interferon- $\gamma$ (IFN- $\gamma$ ), and IgG in the exposed workers were lower than in referents. Combined exposure to Ga, In, and As showed a significant change in trends of decreased MCV, WBCs, neutrophils, lymphocytes, IFN, $\gamma$, and IgG value, after adjusting for appropriate confounders.
\end{abstract}

Conclusion: These findings indicated that heavier exposed to Ga, In, and As may suppress hematological and immunological variables.

Keywords: Light Emitting Diodes; Hematological; Immunological.

\section{Introduction}

Light-emitting diodes (LEDs) manufacturing is a metallicintensive optoelectronic industry. Toxic metals of group III A and $\mathrm{VA}$ of the periodic table are widely used in this industry, such as GaAs, InGaAs, and In GaAsP. These materials are used extensively in the operation of epitaxial growth, and dopant (Robinson 1983, Lay et al. 2002, Tanaka 2004).

In previous studies, occupational exposure to gallium $(\mathrm{Ga})$, indium (In), and arsenic (As) had been described significantly $(\mathrm{p}<0.05)$ higher in exposed group than in referents (Liao et al, 2004. Chen, 2007). These metals or metalloids are known to alter heme synthesis (Woods et al. 1979, Aoki et al. 1990, Flora \& Das Gupta 1992, Hatlelid et al. 1996), initiate apoptosis (Bustamante et al. 1997, Chang et al. 2003, Pyszel et al. 2005, Zhou et al. 2005). And cause carcinogenic effects (Fowler et al. 1993) in experimental studies. Overexposure to $\mathrm{Ga}$ and As have been shown to cause toxic effects of lipid peroxidation in optoelectronic workers (Liao et al. 2006). Exposure to In could cause interstitial lung damage in indium processing and indium compound production workers (Chonan et al. 2007, Hamaguchi et al. 2008). Luo et al suggested that leucopenia was a potential health effect in male fabrication workers in the semiconductor industry (Luo et al. 2002).

Taiwan is a preferred location for optoelectronic producing facilities; the optoelectronic production value has increased by $210 \%$ from 2003 to 2007. Among the optoelectronic facilities, the production value of LED increased along with the expansion of the global photonics market, which has comprised the largest production $(50 \%)$ of the global photonics market since 2005 . For this reason, the number of LED companies and workers has been increasing rapidly. Hematopoietic synthesis and immunological response are general functions of humankind; detection of its abnormality in the blood cell reflects a widespread injury to other tissues (Piomelli 1981, Luster et al. 1993, Goering \& Rehm 1990). Because workers in the optoelectronic factories are potential exposed to $\mathrm{Ga}$, in, and As (Liao et al. 2004), their health may be at risk. The current study is undertaken to evaluate possible hematological and immunological effects of $\mathrm{Ga}$, in, and as among the LED workers. To our knowledge, this is the first report to address the effects of optoelectronic metal in workers.

\section{Methods}

\subsection{Subjects}

We studied subjects from two LED factories in northern Taiwan. They were selected at the time of their annual medical examination between 2000 and 2003. Two workers were excluded because of past history of thyroid, and tumor diseases. Therefore, the final study population consisted of 91 LED workers who worked in the fabrication room (11 fabrication equipment preventative workers, 30 dopants and thin film workers, 25 fabrication supervisors and engineers, and 25 dice checking). And 24 referents (office workers) who worked in offices isolated from the fabrication rooms. Each worker included in the study population completed a questionnaire, including information about age, working duration (months), body mass index (BMI), sex, education level, cigarette smoking, alcohol consumption, regular intake of vitamins, and past history of disease. The study was approved by the Institutional Review Board in Kaohsiung Medical University. All participants were informed and signed consent forms. 


\subsection{Biological monitoring}

Urine specimens and blood sample from the antecubital vein were obtained from the study subjects during their health check- ups in the morning. Subjects were instructed to eat nothing for at least 8 hours prior to blood and urine sampling. Blood and urine specimens were kept at $-20 \mathrm{oC}$ prior to analysis (Pan 1993). Levels of heavy metals were determined by inductively coupled plasmamass spectrometry after microwave dissolution, the detail procedures and quality assurance have been described elsewhere (Liao et al. 2004).

\subsection{Determination of hematological and immunological variables}

Venous blood was collected for blood routine and immunological tests. Blood (whole blood $3 \mathrm{ml}$ in EDTA) was collected for measurinf hematological markers such as complete blood cell (CBC) tests, and WBC differential. Serum was taken from the supernatants of centrifuged blood. Serum tumor necrosis factor $-\alpha$ (TNF$\alpha$ ), interleukin - $1 \beta$ (IL-1 $\beta)$, interferon- $\gamma$ (IFN- $\gamma$ ), IgM, and IgG levels were determined by using commercial- ized ELISA kits (Antigenix America Inc, NY) according to manufacturer's instructions.

All blood samples were collected between 7:00 a.m. and 9:00 a.m. The collected samples were transported to a laboratory for analysis within six hours. The blood tests were analyzed in the laboratory of the Department of Clinical Pathology in the Jean Tide Medical Examination Center. Standard quality control was performed twice daily.

\subsection{Statistics}

All results were presented as the value of means, or median. When two groups were compared. The Student's test (normalized transformation) or Chi-square test were employed. The limit of significance was set at $p<0.05$. The correlations in the various groups were studied by Pearson's regression after the data had been normalized. The data were also subjected to multiple linear regression models to examine the net effects and dose-response relation between exposure situation and hematological, and immunological outcomes. A multiple logistic regression model was used to determine the odd ratio (OR) of abnormal health effects on metals exposure after controlling for other independent variables. All analyses were performed with the SPSS program (SPSS Inc, Chicago, IL) for Windows.

\section{Results}

\subsection{Distribution of demographic characteristic, and exposure biomarkers among study subjects}

The demographic, and levels of metals in human's specimens are showed in table 1 . The mean age $(30.34 \pm 18.20$ years $)$, levels of blood In $(0.15 \pm 0.09 \mathrm{ppb})$, urine $\mathrm{Ga}(0.34 \pm 0.13 \mathrm{ppb})$, and urine As $(25.94 \pm 24.72 \mathrm{ppb})$ were significantly higher in the exposed workers than in the referents.

\subsection{Hematological and immunological effects}

Table 2 shows the mean of hematological and immunological parameters in the exposed group and referents. There were significantly lower value of MCV, WBC, neutrophils, lymphocytes, IFN$\gamma$, and $\mathrm{IgG}$ in the exposed group than in referents. There were higher values of $\mathrm{MCHC}$ in the exposed group than in the referents. The frequency of abnormality with MCHC was significantly higher in exposed group than in referents $(\mathrm{OR}=19.52, \mathrm{P}<0.05)$ There was not any difference between the exposed group and referents in the frequency of abnormality with MCV, WBCs, neutrophils, and lymphocytes.
Table 1: Subjects Characteristics, and Exposure Measures of Exposed Workers $(\mathrm{N}=91)$ and Referents $(\mathrm{N}=24)$.

\begin{tabular}{|c|c|c|}
\hline Items & Exposure group & Referents \\
\hline Age* $^{*}(\mathrm{yrs})$ & $30.34 \pm 18.20$ & $26.04 \pm 5.98$ \\
\hline Duration of employment (months) & $30.16 \pm 5.40$ & $29.63 \pm 15.15$ \\
\hline Body mass index $(\mathrm{kg} / \mathrm{m} 2)$ & $22.97 \pm 4.32$ & $23.90 \pm 5.11$ \\
\hline \multicolumn{3}{|l|}{ Sex } \\
\hline male & 52 & 14 \\
\hline female & 39 & 10 \\
\hline \multicolumn{3}{|l|}{ Education level } \\
\hline$<$ college & 68 & 20 \\
\hline$\geqq$ college & 23 & 4 \\
\hline \multicolumn{3}{|l|}{ Smoking status } \\
\hline no & 79 & 23 \\
\hline yes & 12 & 1 \\
\hline \multicolumn{3}{|l|}{ Alcohol consumption } \\
\hline no & 77 & 23 \\
\hline yes & 14 & 1 \\
\hline \multicolumn{3}{|l|}{ Vitamin complex intake* } \\
\hline no & 68 & 19 \\
\hline yes & 23 & 5 \\
\hline \multicolumn{3}{|l|}{ Blood } \\
\hline $\mathrm{Ga}$ & $0.53 \pm 0.35$ & $0.43 \pm 0.29$ \\
\hline In* & $0.15 \pm 0.09$ & $0.10 \pm 0.08$ \\
\hline As & $6.85 \pm 5.93$ & $6.62 \pm 6.63$ \\
\hline \multicolumn{3}{|l|}{ Urine (ppb) } \\
\hline $\mathrm{Ga} *$ & $0.34 \pm 0.13$ & $0.17 \pm 0.11$ \\
\hline In & $0.02 \pm 0.03$ & $0.01 \pm 0.02$ \\
\hline As* & $29.94 \pm 24.72$ & $19.03 \pm 18.14$ \\
\hline
\end{tabular}

$* \mathrm{X} 2$ test: exposure group versus referents, $\mathrm{df}=1, \mathrm{p}<0.05$.

Table 2: Comparison of Hematological and Immunological Parameters between Exposed Group ( $\mathrm{N}=91)$ and Referents $(\mathrm{N}=24)$.

\begin{tabular}{|c|c|c|}
\hline Parameter & Exposure group & Referents \\
\hline \multicolumn{3}{|l|}{$\overline{\mathrm{CBC}}$ differential } \\
\hline $\mathrm{RBC}(\mathrm{m} / \mu \mathrm{L})$ male & $5.05 \pm 0.53$ & $5.02 \pm 0.46$ \\
\hline (low, normal, high) & $(4,37,11)$ & $(0,5,0)$ \\
\hline female & $4.35 \pm 0.43$ & $4.75 \pm 0.55$ \\
\hline (low, normal, high) & $(9,29,1)$ & $(3,13,3)$ \\
\hline $\mathrm{Hb}(\mathrm{g} / \mathrm{dL})$ male & $14.99 \pm 1.60$ & $13.14 \pm 1.98$ \\
\hline (low, normal, high) & $(9,43,0)$ & $(3,2,0)$ \\
\hline Female & $13.15 \pm 1.94$ & $13.16 \pm 1.48$ \\
\hline (low, normal, high) & $(8,27,4)$ & $(4,15,0)$ \\
\hline Hct $(\%)$ male & $46.74 \pm 3.06$ & $45.50 \pm 1.82$ \\
\hline (low, normal, high) & $(2,50,0)$ & $(0,5,0)$ \\
\hline female & $39.21 \pm 4.41$ & $38.64 \pm 3.56$ \\
\hline (low, normal, high) & $(9,30,0)$ & $(8,10,1)$ \\
\hline $\operatorname{MCV}^{*}(\%)$ & $84.32 \pm 7.68$ & $89.77 \pm 5.96$ \\
\hline (low, normal, high) & $(9,79,3)$ & $(0,23,1)$ \\
\hline $\mathrm{MCH}(\mathrm{pg})$ & $29.75 \pm 3.18$ & $29.55 \pm 2.74$ \\
\hline (low, normal, high) & $(8,75,8)$ & $(3,20,1)$ \\
\hline $\operatorname{MCHC}^{*}(\%)$ & $35.49 \pm 4.65$ & $32.89 \pm 1.67$ \\
\hline (low, normal, high) & $(8,42,41)$ & $(3,20,1)$ \\
\hline Platelet $(\mathrm{k} / \mu \mathrm{L})$ & $245.34 \pm 56.44$ & $243.58 \pm 40.0$ \\
\hline (low, normal, high) & $(3,87,1)$ & $(0,24,0)$ \\
\hline $\mathrm{WBC}^{*}(\mathrm{k} / \mu \mathrm{L})$ & $5.82 \pm 1.13$ & $6.96 \pm 1.54$ \\
\hline (low, normal, high) & $(20,71,0)$ & $(1,23,0)$ \\
\hline \multicolumn{3}{|c|}{ WBC differential $(\mathrm{k} / \mu \mathrm{L})$} \\
\hline Neutrophils* & $3.02 \pm 1.23$ & $3.92 \pm 1.34$ \\
\hline (low, normal, high) & $(15,76,0)$ & $(1,23,0)$ \\
\hline Lymphocytes* & $2.12 \pm 0.61$ & $2.44 \pm 0.77$ \\
\hline (low, normal, high) & $(1,90,0)$ & $(0,24,0)$ \\
\hline Monocytes & $0.32 \pm 0.22$ & $0.26 \pm 0.19$ \\
\hline (low, normal, high) & $(0,90,1)$ & $(0,24,0)$ \\
\hline Eosinophils & $0.30 \pm 0.20$ & $0.31 \pm 0.19$ \\
\hline (low, normal, high) & $(0,90,1)$ & $(0,24,0)$ \\
\hline Basophils & $0.06 \pm 0.07$ & $0.03 \pm 0.05$ \\
\hline (low, normal, high) & $(0,86,5)$ & $(0,23,1)$ \\
\hline \multicolumn{3}{|l|}{ Immune markers } \\
\hline $\mathrm{TNF}-\alpha(\mathrm{pg} / \mathrm{mL})$ & $6.35 \pm 0.79$ & $6.43 \pm 0.82$ \\
\hline $\mathrm{IL}-1 \beta(\mathrm{pg} / \mathrm{mL})$ & $3.18 \pm 0.41$ & $3.31 \pm 0.37$ \\
\hline IFN- $\gamma^{*}(\mathrm{pg} / \mathrm{mL})$ & $20.81 \pm 3.83$ & $25.49 \pm 3.47$ \\
\hline $\operatorname{IgM}(\mathrm{mg} / \mathrm{dL})$ & $87.92 \pm 18.33$ & $93.42 \pm 21.94$ \\
\hline $\mathrm{IgG}^{*}(\mathrm{mg} / \mathrm{dL})$ & $1241.10 \pm 199.59$ & $1376.42 \pm 206.23$ \\
\hline
\end{tabular}

*: Student's t test, significant difference, $\mathrm{p}<0.05$ (exposed workers vs. referents, $\mathrm{df}=1$, all data had been normalized) 


\subsection{Dose-response relation between biomarkers and hematological and immunological effects}

Among the 91 LED workers, blood In, urine Ga and As levels were negatively and significantly correlated $(\mathrm{p}<0.05)$ with $\mathrm{MCV}$, WBCs, neutrophils, lymphocytes, IFN- $\gamma$, and IgG values respectively (table 3 ). Based on the analysis of hematological and immunological parameters among the 91 LED worker, Ga showed higher coefficients of determination for MCV (r 2=0.49), WBC $(\mathrm{r} 2=0.42)$, neutrophils $(\mathrm{r} 2=0.26)$, lymphocytes $(\mathrm{r} 2=0.44)$, IFN$\gamma(\mathrm{r} 2=0.26)$, and $\operatorname{IgG}(\mathrm{r} 2=0.69)$ values respectively than In, and As.

Among the 24 office workers, there was no significant correlation between any metal in blood or urine and hematological or immunological parameters in referents.

Table 3: The Pearson's Correlation Coefficient between Biomarkers and Hematological and Immunological Parameters.

\begin{tabular}{|c|c|c|c|}
\hline & Exposure group & Referents & Total \\
\hline \multicolumn{4}{|l|}{ Blood } \\
\hline In vs MCV & $-0.35^{*}$ & 0.03 & $-0.32 *$ \\
\hline In vs MCHC & 0.02 & -0.10 & 0.06 \\
\hline In vs WBCs & $-0.39 *$ & 0.12 & $-0.31 *$ \\
\hline In vs neutrophils & $-0.22 *$ & 0.32 & -0.26 \\
\hline In vs lymphocytes & $-0.23^{*}$ & -0.19 & $-0.25^{*}$ \\
\hline In vs IFN- $\gamma$ & $-0.27 *$ & 0.13 & $-0.27 *$ \\
\hline In vs IgG & $-0.51 *$ & 0.01 & $-0.43^{*}$ \\
\hline \multicolumn{4}{|l|}{ Urine } \\
\hline $\mathrm{Ga}$ vs $\mathrm{MCV}$ & $-0.70 *$ & 0.14 & $-0.63 *$ \\
\hline Ga vs MCHC & 0.17 & 0.15 & $0.26^{*}$ \\
\hline Ga vs WBCs & $-0.65^{*}$ & 0.07 & $-0.57 *$ \\
\hline Ga vs neutrophils & $-0.51 *$ & -0.08 & $-0.50 *$ \\
\hline Ga vs lymphocytes & $-0.21^{*}$ & 0.26 & $-0.19 *$ \\
\hline Ga vs IFN- $\gamma$ & $-0.51^{*}$ & 0.29 & $-0.51 *$ \\
\hline Ga vs IgG & $-0.83^{*}$ & 0.13 & $-0.68 *$ \\
\hline As vs MCV & $-0.34^{*}$ & 0.09 & $-0.32 *$ \\
\hline As vs MCHC & -0.04 & 0.25 & 0.04 \\
\hline As vs WBCs & $-0.25^{*}$ & -0.23 & $-0.29 *$ \\
\hline As vs neutrophils & 0.14 & -0.38 & -0.24 \\
\hline As vs lymphocytes & $-0.26^{*}$ & 0.29 & -0.17 \\
\hline As vs IFN- $\gamma$ & $-0.32 *$ & 0.15 & $-0.30 *$ \\
\hline As vs IgG & $0.54 *$ & 0.14 & $-0.44 *$ \\
\hline
\end{tabular}

\subsection{Combined exposure to in, GA and as and hemato- logical and immunological effects}

In multiple regression analysis. Exposed workers affected negatively and significantly MCV $(\beta=-0.33, p<0.05)$, WBC $(\beta=-$ $0.37, \mathrm{p}<0.05)$, neutrophils $(\beta=-0.27, \mathrm{p}<0.05)$, lymphocytes $(\beta$ $=-0.25, \mathrm{p}<0.05), \operatorname{IFN}-\gamma(\beta=-0.52, \mathrm{p}<0.05)$, and $\operatorname{IgG}(\beta=-0.34$ $\mathrm{p}<0.05)$ values than the office workers $(\mathrm{p}<0.05)$ after adjusting for another factor, including duration of employment, BMI, sex, education level, cigarette smoking, alcohol consumption, regular intake of vitamins, and past history of disease (table4).

\section{Discussion}

This study showed an elevated blood. In, urine Ga, urine. As, blood MCHC, but decreased blood MCV, WBCs, neutrophils, lymphocytes, IFN- $\gamma$, and IgG values in workers exposed to $\mathrm{Ga}$, In, and As when compared with the referents. Association analysis showed that blood. In, urine $\mathrm{Ga}$, and urine. As levels had significant correlation with blood MCV, WBCs, neutrophils, lymphocytes, IFN- $\gamma$, and IgG in exposed workers respectively. Ga showed the highest coefficient of determination for the hematological and immunological parameters than In, and As. In multiple regression analysis, the dose-response relationships were found between the cumulative biological exposed dose and MCV, WBCs, neutrophils, lymphocytes, IFN- $\gamma$, and IgG. These results implied that heavier exposure to $\mathrm{Ga}$, In, and As may suppress the hematological and immunological variables in the LED workers.
The finding of reduced MCV, WBCs neutrophils, and lymphocytes was consistent with other reports in the literatures (Luo et al. 2002, Heck et al. 2008). Several murine in vitro and in vivo studies have demonstrated the effects of $\mathrm{Ga}$, In, and As on lymphocyte proliferation and on immunoglobulin production (Balaban et al. 1987, Gonsebatt et al. 1992, Huang et al. 1994, Drobyski et al. 1996, Gondre-Lewis et al. 2003). Chitambar et al suggested that transferring-gallium complex (Tf-Ga) capable of targeting Tf receptor-bearing T- and B- lymphocytes and interferes with their proliferation and function (Chitambar et al. 1989). The cytokines induced by helper $\mathrm{T}$ cells might not only opsonise the inflammatory systems but also affect the proliferative response of splenic $B$ blast cells (Romaganani 1997, Chang et al. 2002). The results showed that at the counts (WBC, neutrophil, and lymphocyte) and levels (IFN- $\alpha$, and IgG) tests, combined exposure to Ga, In, and As could impair the subtle lymphocyte stimulation and proliferation. We found exposed who were older workers could be protected from a decline of IFN- $\alpha$, and IgG. The effects of age on IFN- $\alpha$, and $\operatorname{IgG}$ were not known, and should be further investigated.

Table 4: Linear Regression Models of the Hematological and Immunological Parameters of Exposure Situation Adjusted for Potential Confounders Respectively $(\mathrm{N}=115)$.

\begin{tabular}{|c|c|c|c|c|c|c|}
\hline Variables & $\begin{array}{l}\mathrm{MC} \\
\mathrm{V}\end{array}$ & $\begin{array}{l}\text { WBC } \\
\mathrm{s}\end{array}$ & $\begin{array}{l}\text { Neutro- } \\
\text { phils }\end{array}$ & $\begin{array}{l}\text { Lympho- } \\
\text { cytes }\end{array}$ & $\begin{array}{l}\text { IFN- } \\
\gamma\end{array}$ & IgG \\
\hline \multicolumn{7}{|l|}{$\begin{array}{l}\text { Regression } \\
\text { coefficient } \\
\text { (ß) }\end{array}$} \\
\hline $\begin{array}{l}\text { Exposure } \\
\text { (Referents } \\
=0 \text { ) }\end{array}$ & $\begin{array}{l}- \\
0.33 \\
*\end{array}$ & $-\overline{0.37 *}$ & $-0.27 *$ & $-0.35 *$ & $\begin{array}{l}- \\
0.52 \\
*\end{array}$ & $\begin{array}{l}- \\
0.34\end{array}$ \\
\hline $\begin{array}{l}\text { Duration } \\
\text { of em- } \\
\text { ployment }\end{array}$ & 0.11 & -0.03 & 0.03 & -0.05 & 0.08 & 0.09 \\
\hline Age (yrs) & 0.08 & 0.10 & 0.05 & 0.11 & $\begin{array}{l}0.23 \\
*\end{array}$ & $\begin{array}{l}0.24 \\
*\end{array}$ \\
\hline $\begin{array}{l}\text { BMI } \\
(\mathrm{kg} / \mathrm{m} 2)\end{array}$ & $-\overline{0.10}$ & -0.07 & -0.08 & 0.00 & - & $-\overline{0.07}$ \\
\hline $\begin{array}{l}\text { Sex (male } \\
=0)\end{array}$ & $\begin{array}{l}- \\
0.05\end{array}$ & 0.08 & 0.15 & -0.17 & $\overline{-}-08$ & - \\
\hline $\begin{array}{l}\text { Education } \\
\text { level }(< \\
\text { college = } \\
0)\end{array}$ & 0.08 & 0.08 & 0.14 & -0.09 & 0.02 & $\overline{-} .04$ \\
\hline $\begin{array}{l}\text { Smoking } \\
\text { status (no } \\
=0 \text { ) }\end{array}$ & 0.08 & 0.15 & 0.08 & 0.10 & 0.02 & $\overline{-} .00$ \\
\hline $\begin{array}{l}\text { Alcohol } \\
\text { consump- } \\
\text { tion }(n=0)\end{array}$ & $\overline{0} .13$ & -0.13 & -0.04 & -0.15 & $\overline{0}-10$ & $\overline{-}$ \\
\hline $\begin{array}{l}\text { Vitamin } \\
\text { complex } \\
\text { intakes (no } \\
=0 \text { ) }\end{array}$ & 0.16 & 0.03 & 0.09 & -0.21 & $\overline{-}-08$ & 0.02 \\
\hline
\end{tabular}

$\mathrm{P}$ value $<0.05$, significant difference. All data had been normalized.

\section{Acknowledgments}

This study was financially supported by the Shin Horng Machinery Individual Company Taichung, Taiwan.

\section{References}

[1] Aoki Y, Lipsky MM, \& Fowler BA (1990). Alternation of protein synthesis in primary culture of rat kidney epithelial cells by exposure to $\mathrm{Ga}$, in, and as (1990). Toxicology \& Apl Pharm 106, 462 - 468. http://dx.doi.org/10.1016/0041-008X(90)90341-Q.

[2] Balaban M E, Simon TR, \& Frenkel EP (1987). Toxicity of indium111 on the radiolabeled lymphocyte. J Nucl Med 28, 229 - 233.

[3] Bustamante J, Dock L, Vahter M, Fowler B, \& Orrenius S (1997). The semiconductor elements arsenic and indium induce apoptosis in rat $\begin{array}{lllll}\text { thymocytes. } & \text { Toxicology } & 118, & 129 & -\end{array}$ http://dx.doi.org/10.1016/S0300-483X(96)03607-4. 
[4] Chang MP, Wang Q, \& Norman DC (2002). Diminished proliferation of B blast cell in response to cytokines in ethanol-consuming mice 24 $69-82$.

[5] Chang KL, Liao WT, Yu CL, Cheng CE, Chang LW, \& Yu HS (2003) Effects of $\mathrm{Ga}$ on immune stimulation and apoptosis induction in human peripheral blood mononuclear cells. Toxicol Appl Pharmacol 193, 209 - 217. http://dx.doi.org/10.1016/j.taap.2003.07.004.

[6] Chen HW (2007). Exposure and health risk of gallium, indium, and arsenic from semiconductor manufacturing industry workers. Bull Environ Contam Toxicol 78, $123 \quad-\quad 127$. http://dx.doi.org/10.1007/s00128-007-9079-9.

[7] Chitambar CR, Seigneuret MC, Matthaeus WG, \& Lum LG (1989). Modulation of lymphocyte proliferation and immunoglobulin production by transferring-gallium. Cancer Res 49, 1125 - 1129.

[8] Chonan T, Taguchi O, \& Omae K (2007). Interstitial pulmonary disorders in indium-processing workers. Eur Respir J 29, 317 - 324. http://dx.doi.org/10.1183/09031936.00020306.

[9] Drobyski WR, UI-Haq R, Majewski D, \& Chitambar CR (1996) Modulation of in vitro and in vivo T-cell response by by transferringgallium nitrate. Blood 88, 3056-3064.

[10]Flor SJ \& Das Gupta S (1992). Effect of single arsenide exposure on some biochemical variables in propyrin metabolism in rats. J Appl Toxicol 12, 333 - 334. http://dx.doi.org/10.1002/jat.2550120508.

[11]Fowler BA, Yamauchi H, Conner EA, \& Akkerman M (1993). Cancer risks for humans from exposure to the semiconductor metals. Scand J Work Environ Health 19, $101-103$.

[12] Gondre-Lewis TA, Hartmann CB, Caffrey RE, \& McCor KL (2003). Gallium arsenide exposure impairs splenic B cell accessory function. Int Immunopharmacol 3, 403 - 415. http://dx.doi.org/10.1016/S15675769(03)00007-9.

[13]Gonsebatt ME, Vega L, Herrera LA, Rojas E, Cebrian ME, \& Ostrosky-Wegman P (1992). Inorganic arsenic effects on human lymphocyte stimulation and proliferation 283, $91-95$.

[14]Hamaguchi T, Omae K, Takebayashi T, Yikuchi Y, Yoshioka N, Nishiwaki Y, Tanaka A, Hirata M, Taguchi O, \& Chonan T (2008). Exposure to hardly soluble indium compounds in ITO production and recycling plants is new risk interstitial lung damage. Occup Environ Med 65, 51 - 55. http://dx.doi.org/10.1136/oem.2006.029124.

[15]Hatlelid KM, Brailsford C, \& Carter DE (1996). Reactions of arsine with hemoglobin. Journal of Toxicology and Environmental Health 47, 145 - 157. http://dx.doi.org/10.1080/009841096161852.

[16]Heck JH, Chen Y, Grann VR, Siavkovich V, Faruque P, \& Habibul A (2008).Arsenic exposure and anemia in Bangladesh: a populationbased study. J Occup Environ Med 50, 80- 87. http://dx.doi.org/10.1097/JOM.0b013e31815ae9d4.

[17]Huang EH, Gabler DM, Krecic ME, Gerber N, Ferguson RM, \& Prosz CG (1994). Differential effects of gallium nitrate on T lymphocyte and endothelial cell activation. Transplantation 58, $1216-1222$. http://dx.doi.org/10.1097/00007890-199412270-00014.

[18] Lay tS, Fan HP, hsu HT, \& Cheng TY (2002). Electro-modulation spectroscopy and laser performance of an InGaAsP asymmetric multiquantum-well structure. Optics Communica-tionss 211, $289-294$.

[19]Liao YH, Hwang LC, Kuo JS, Yiin SJ, Lin SF, Lin CH, \& Aw TC (2006). Lipid peroxidation in workers exposed to $\mathrm{Al}, \mathrm{Ga}, \mathrm{In}, \mathrm{As}$, and $\mathrm{Sb}$ in the optoelectronic industry. J Occup Environ Med 48, 789 - 793. http://dx.doi.org/10.1097/01.jom.0000229782.71756.8e.

[20]Liao YH, Yu HS, Ho CK, Wu MT, Yang CY, Chen JR, \& Chang CC (2004). Biological monitoring of exposure to $\mathrm{Al}, \mathrm{Ga}, \mathrm{In}, \mathrm{As}$, and $\mathrm{Sb}$ in optoelectronic industry workers. J Occup En-viron Med 46, 931 936. http://dx.doi.org/10.1097/01.jom.0000137718.93558.b8.

[21]Luo JC, Hsieh LL, Chang MJ, Hsu KH (2002). Decreased white blood cell counts in semiconductor manufacturing workers in Taiwan. Occup Environ Med 59, 44 - 49. http://dx.doi.org/10.1136/oem.59.1.44.

[22]Pan TC, Horng CJ, Lin SR, Lin TH, \& Huang CW (1993). Stimultaneous determination of $\mathrm{Zn}, \mathrm{Cd}, \mathrm{Pb}$, and $\mathrm{Cu}$ in urine of patient with blackfoot disease using anodic stripping voitammetry. Biol Trace Element Res 38, 233- 250. http://dx.doi.org/10.1007/BF02785308.

[23]Piomelli S (1981). Chemical toxicology of red cells. Environmental Health Perspectives 39, $65-70$ http://dx.doi.org/10.1289/ehp.813965.

[24]Pyszel A, Wrobel T, Szuba A, \& Andrzejak R (2005). Effect of administration styles of arsenic trioxide on intracellular arsenic concentration, cell differentiation and apoptosis. Haematologica 90, 1277 1279.

[25]Robinson AL (1983). GAAS readied for high-speed mi-crocircuits. Science $219,275-277$. http://dx.doi.org/10.1126/science.219.4582.275.

[26]Romaganani S (1997). The Th1/Th2 paradigm. Immunol-ogy Today 18, 263 - 266. http://dx.doi.org/10.1016/S0167-5699(97)80019-9.
[27] Tanaka A (2004). Toxicology of indium arsenide, gallium arsenide, and aluminium gallium arsenide. Toxicol Appl Pharmacol 198, $405-$ 411. http://dx.doi.org/10.1016/j.taap.2003.10.019.

[28] Woods JS, Carver GT, \& Fowler BA (1979). Altered regu-lations of hepatic heme metabolism by indium chloride. Toxicology \& Applied Pharmacology 49, 455 - 461. http://dx.doi.org/10.1016/0041008X(79)90446-0.

[29]Zhou J, Meng R, Sui X, Meng L, Jia J, \& Yang B (2005). Effects of administration styles of arsenic trioxide on intracellular as concentration, cell differentiation and apoptosis. Haematologica 90, $1277-$ 1279 . 